University of Nebraska - Lincoln

DigitalCommons@University of Nebraska - Lincoln

Faculty Publications from the Harold W. Manter Laboratory of Parasitology

2005

\title{
Hesperoctenes fumarius (Hemiptera: Polyctenidae) Infesting Molossus rufus (Chiroptera: Molossidae) in Southeastern Brazil
}

\author{
Carlos E. L. Esbérard \\ Projeto Morcegos Urbanos \\ Andrea C. Jesus \\ Projeto Morcegos Urbanos \\ Adarene G. Motta \\ Projeto Morcegos Urbanos \\ Helena G. Bergallo \\ Universidade do Estado do Rio de Janeiro \\ Donald Gettinger \\ University of Nebraska-Lincoln, donaldgettinger@gmail.com
}

Follow this and additional works at: https://digitalcommons.unl.edu/parasitologyfacpubs

Part of the Parasitology Commons

Esbérard, Carlos E. L.; Jesus, Andrea C.; Motta, Adarene G.; Bergallo, Helena G.; and Gettinger, Donald, "Hesperoctenes fumarius (Hemiptera: Polyctenidae) Infesting Molossus rufus (Chiroptera: Molossidae) in Southeastern Brazil" (2005). Faculty Publications from the Harold W. Manter Laboratory of Parasitology. 684.

https://digitalcommons.unl.edu/parasitologyfacpubs/684

This Article is brought to you for free and open access by the Parasitology, Harold W. Manter Laboratory of at DigitalCommons@University of Nebraska - Lincoln. It has been accepted for inclusion in Faculty Publications from the Harold W. Manter Laboratory of Parasitology by an authorized administrator of DigitalCommons@University of Nebraska - Lincoln. 
Esbérard, Jesus, Motta, Bergallo \& Gettinger in Journal of Parasitology (2005) 91.

\section{Hesperoctenes fumarius (Hemiptera: Polyctenidae) Infesting Molossus rufus (Chiroptera: Molossidae) in Southeastern Brazil}

Carlos E. L. Esbérard, Andrea C. Jesus`, Adarene G. Motta*, Helena G. Bergallo†, and Donald Gettingerł, Programa de PósGraduação, Universidade do Estado do Rio de Janeiro, Rua São Francisco Xavier 524, 20559-900, Rio de Janeiro, RJ, Brazil; *Projeto Morcegos Urbanos, Fundação RIOZOO, Quinta da Boa Vista s.no., 20940-040, Rio de Janeiro, RJ, Brazil; †Departamento de Ecologia, Universidade do Estado do Rio de Janeiro, Rua São Francisco Xavier 524, 20559-900, Rio de Janeiro, RJ, Brazil; ¥Manter Laboratory of Parasitology, University of Nebraska, Lincoln, Nebraska 68588-0514. e-mail: cesberard@terra.com.br

ABSTRACT: We analyzed the prevalence, intensity, and medium density of parasitism of Hesperoctenes fumarius infesting Molossus rufus in natural (hollow trees) and anthropogenic roosts (attics) in southeastern Brazil. The prevalence and intensity of infestations were higher in the hollow trees than in the attic roosts. We also noted a relationship between the amount of space available within the roost and the infestation levels of $H$. fumarius. One advantage of roosting in larger, often manmade, refuges may be the reduction in ectoparasite infestations.

Polyctenid bugs, or "batbugs" (Hemiptera: Polyctenidae), are bloodsucking ectoparasites of bats, commonly associated with the Molossidae in the Neotropics (Marshall, 1991). In southeastern Brazil, these ectoparasites are commonly collected from the pelage of Molossus rufus (E Geoffroy, 1805), a medium-sized (33 g), insectivorous bat that frequently uses roofs and attics of houses and buildings as roosts (Marques, 1986; Fenton et al., 1998; Esbérard, 2002). This bat species prefers roosts where the temperature is elevated, usually by a combination of factors including the general insolation of the roost, the number and density of bats, and the decomposition of feces and urine. The colonies of $M$. rufus are large, often exceeding 500 individuals (Marques, 1986), but numbers vary through time, depending on reproduction, immigra-

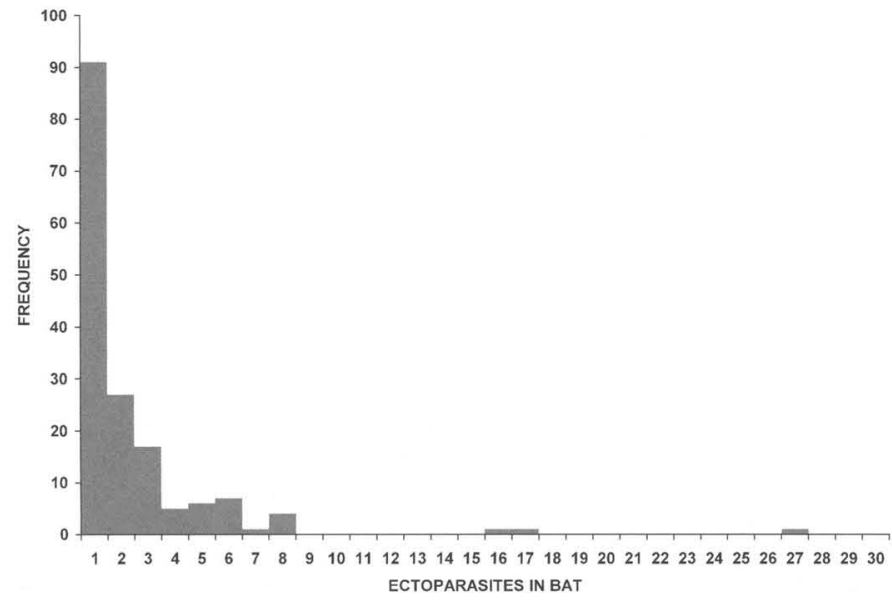

FigURE 1. Frequency of Hesperoctenes fumarius on Molossus rufus in 3 refuges sampled in southeastern Brazil. tion, and emigration (Esbérard, 2002). In natural conditions, these bats often roost in hollow trees, and Esberard et al. (2003) observed that individuals commonly returned to the same roost through 4 reproductive seasons. However, roost fidelity may have costs, i.e., long-term use of the same roosts may increase the probability of heavy parasite burdens (Lewis, 1995). In this article, we examine the parasitism of a polyctenid bug, Hesperoctenes fumarius, associated with the molossid bat, $M$. rufus, by comparing the infestation levels of natural and anthropogenic roosts in southeastern Brazil.

We sampled populations of polyctenid bugs infesting $M$. rufus in 3 roosts in southeastern Brazil, Rio de Janeiro State. Two were natural roosts, and the third was anthropogenic. Roost no. 1 was in a hollow "pau-d'alho" tree (Agonandra brasiliensis, Olacaeae), extending from a point $0.4 \mathrm{~m}$ from ground level to a height of $3.2 \mathrm{~m}$, with roost space estimated at $3 \mathrm{~m}^{3}$ and access from above; this roost was located in the Fazenda Ventania, Municipality of Casimiro de Abreu (22 $33^{\prime} 13.98^{\prime \prime} \mathrm{S}$, $42^{\circ} 00^{\prime} 35.82^{\prime \prime} \mathrm{W}$ ). Roost no. 2 was also in a hollow pau-d'alho tree, extending from the level of the ground to a height of $2.2 \mathrm{~m}$, with a roos

TABLE I. Data of the collections, number of bats, number of positive bats, and total ectoparasites (Hesperoctenes fumarius) collected in the 3 roosts in the State of Rio de Janeiro, southeastern Brazil.

\begin{tabular}{clccc}
\hline $\begin{array}{c}\text { Roost } \\
\text { nos. }\end{array}$ & \multicolumn{1}{c}{ Date } & $\begin{array}{c}\text { Size of } \\
\text { colony }\end{array}$ & $\begin{array}{c}\text { Positive } \\
\text { bats }\end{array}$ & $\begin{array}{c}\text { Number of } \\
\text { ectoparasites }\end{array}$ \\
\hline 1 & 24 May 2003 & 34 & 26 & 98 \\
1 & 06 September 2003 & 60 & 32 & 84 \\
2 & 11 November 2000 & 29 & 10 & 10 \\
2 & 24 March 2001 & 59 & 19 & 35 \\
2 & 28 April 2001 & 26 & 11 & 11 \\
2 & 21 July 2001 & 37 & 32 & 47 \\
2 & 29 September 2001 & 14 & 2 & 4 \\
2 & 02 November 2001 & 39 & 19 & 42 \\
3 & 13 January 2001 & 68 & 7 & 7 \\
3 & 17 March 2001 & 92 & 5 & 6 \\
3 & 21 April 2001 & 64 & 4 & 4 \\
3 & 02 June 2001 & 57 & 3 & 3 \\
3 & 25 July 2001 & 23 & 2 & 2 \\
3 & 20 October 2001 & 57 & 9 & 15 \\
3 & 02 November 2001 & 113 & 11 & 19 \\
\hline
\end{tabular}


Esbérard, Jesus, Motta, Bergallo \& Gettinger in Journal of Parasitology (2005) 91.

Copyright 2005, American Society of Parasitologists. Used by permission.
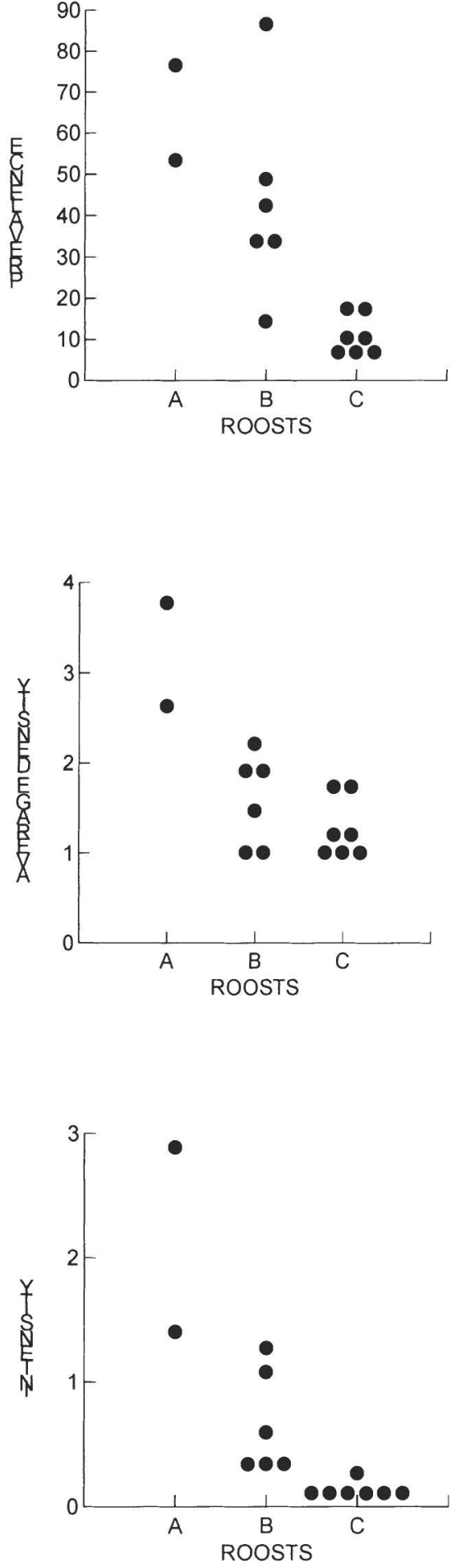

FIGURE 2. Parasitism of Hesperoctenes fumarius on Molossus rufus in southeastern Brazil. A. Refuge in a hollow tree of $4 \mathrm{~m}^{3}$. B. Refuge in a hollow tree with $3 \mathrm{~m}^{3}$. C. Attic of house.

space estimated at $4 \mathrm{~m}^{3}$, with access from above; it was located in the Fazenda da Barra, Municipality of Casimiro de Abreu $\left(22^{\circ} 33^{\prime} 03.3^{\prime \prime} \mathrm{S}\right.$, $\left.42^{\circ} 03^{\prime} 02^{\prime \prime} \mathrm{W}\right)$. Roost no. 3 was an enclosed space under the slate-roof of a building, with a roost area estimated at $30 \mathrm{~m}^{3}$; there were large areas of empty space and 3 entrances by holes on the wall, located in the Biological Reserve of Poço das Antas, Municipality of Silva Jardim $\left(22^{\circ} 33^{\prime} 39.2^{\prime \prime} \mathrm{S}, 42^{\circ} 16^{\prime} 19.3^{\prime \prime} \mathrm{W}\right)$. In all 3 roosts, M. rufus shared space

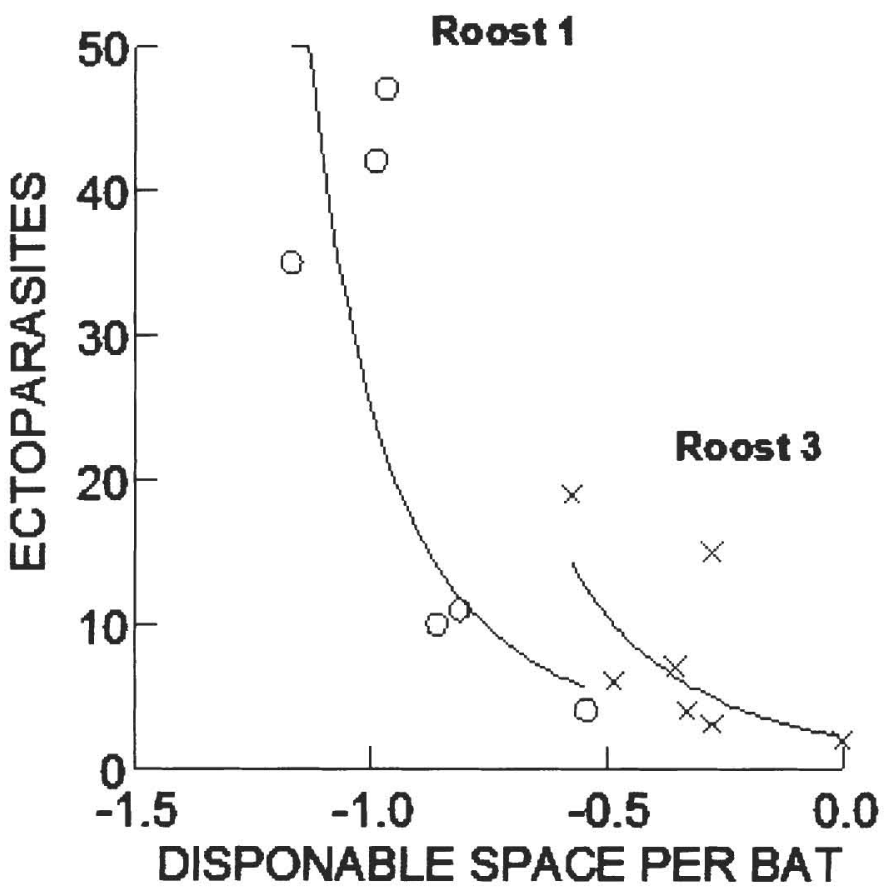

FIGURE 3. Variation of available space per bat $\left(\mathrm{m}^{3}\right)$ and the number of bats and the number of ectoparasites collected in 2 of the roosts sampled in southeastern Brazil. The circles represent the sample from the hollow tree (roost no. 1) and the crosses the collection from the attic of a house (roost no. 3 ).

with another bat, the large phyllostomid, Phyllostomus hastatus; parasitism with $H$. fumarius was never observed in these cohabiting bats.

Each roost was sampled for 2-7 nights using mist nets opened all night next to the entrances or in the case of the anthropogenic roost. modified Davis traps (Esbérard, 2002, 2003). Captured bats were individually marked with plastic collars provided with colored beads following an established code (see Esbérard and Daemon, 1999). The bats were examined carefully; all batbugs were removed with forceps and preserved in vials of $70 \%$ ethanol. After marking and sampling for ectoparasites, the bats were released at the point of capture.

We analyzed the prevalence (proportion of bat individuals infested), the intensity of infestation (mean number of batbugs sampled per host sample or the total colony), and medium density of parasitism (mean number of batbugs per infested host sample) (Margolis et al., 1982). The prevalence, intensity, and medium density of the 3 roosts were compared with an analysis of variance realized through SYSTAT 7.0 The aggregation of parasites was calculated by the formula $\mathrm{k}=\mathrm{m}^{2} /\left(\mathrm{s}^{2}\right.$ $-\mathrm{m})$, where $\mathrm{s}=$ variance and $\mathrm{m}=$ mean of parasites per host. This index indicates whether the distribution of the parasite tends to be random $(\mathrm{k}>20)$ or aggregated $(\mathrm{k}=1)$ (Wilson et al., 2002).

Molossus rufus was captured 762 times and found positive for $H$. fumarius on 161 occasions (21\%), with a total of 387 batbug ectoparasites collected (Table I). The number of ectoparasites per bat varied from 1 to 27 , with a medium of $2.22 \pm 2.86$ and mode of 1 ectoparasite per bat $(52.5 \%)$. Three samples displayed elevated infestations (more than 15 ectoparasites per bat), corresponding to $16.2 \%$ of the ectoparasites collected $(\mathrm{k}=0.0068)$, demonstrating that this parasite displays an aggregated distribution (Fig. 1).

The prevalence showed variation among the 3 roosts analyzed, the 2 hollow trees (roosts nos. 1 and 2) were represented by mean prevalences $(48.54 \pm 23.67 \%)$ higher than the attic (roost no. 3) $(8.78 \% \pm 3.70)$ $\left(F_{2,12}=12.07, P=0.001\right)$. The prevalence differed between roost nos. 1 and $3(P=0.003)$ and roost no. 2 with no. $3(P=0.008)$ (Fig. 2$)$. The intensity presented a similar pattern, with the hollow trees presenting values higher $(1.035 \pm 0.863)$ than the attic $(0.115 \pm 0.076)$ $\left(F_{2,12}=19.48, P<0.001\right)$. Only roost nos. 2 and 3 did not differ significantly $(P=0.074)$ (Fig. 2$)$. The medium density varied $\left(F_{2.12}=\right.$ $13.80, P=0.001)$ among the 3 roosts considered, although roost nos. 
Esbérard, Jesus, Motta, Bergallo \& Gettinger in Journal of Parasitology (2005) 91.

2 and 3 did not differ significantly $(P=0.382$ ) (Fig. 2). Of the 2 most sampled roosts, a clear relationship was observed between the space available for the bats (roost space) and the number of ectoparasitic batbugs collected (Fig. 3).

The size of the bat colony varies seasonally, with largest concentrations observed during the reproductive season (Esbérard, 2002). Less roost space imposes higher contact between the bats and, consequently, increases the probability of parasitism. Larger spaces may permit, and even maintain, more plentiful colonies and can result in dilution of the number of ectoparasites infesting the colony. The use of anthropogenic roosts, generally with larger amounts of available roost space, is shown to have advantages in avoiding parasitism. Also, living in an urban area often provides an elevated availability of prey for insectivorous bats because insects are attracted to artificial illumination. Molossus rufus is a common bat in urban areas of southeastern Brazil and frequently roosts in roofs and attics of houses and buildings (Esbérard et al., 1999). Various species change localities to avoid parasites (Lewis, 1995). This bat uses the refuge for short periods of time, being sited 3 mo of each year (Esbérard, 2002), and this can be a strategy to limit the chance of elevated infestation by parasites.

We thank Gustavo Gracioli for the identification of the voucher material. We thank the Secretaria de Agricultura e Pesca de Casimiro de Abreu that paid for part of the resources necessary for this work. We thank the Reserva Biológica de Poço das Antas (Processo 02045.000233/00-68) and the Fazenda da Barra for permission to collect. We thank the Associação Mico Leão for the use of their installations and João Branco (SMAP - Casimiro Abreu) e Carlos (Fazenda da Barra) for their support in the realization of this project. We thank Adriene Areas and Débora Moraes for help with the fieldwork. Ludmilla Aguiar and Cristina Nassar edited a version of this work. During these proceedings H.G.B. received a research grant from $\mathrm{CNPq}$.

\section{LITERATURE CITED}

EsBÉRARD, C. 2002. Composição de colônia e reprodução de Molossus rufus (E. Geoffroy) (Chiroptera, Molossidae) em um refúgio no sudeste do Brasil. Revista Brasileira de Zoologia 19: 1153-1160.
2003. Armadilha para retirada de morcegos abrigados em telhado. Chiroptera Neotropical 9(1-2): 164-166.

, A. S. Chagas, And E. M. Luz. 1999. Uso de residências por morcegos no Estado do Rio de Janeiro (Mammalia: Chiroptera). Revista Brasileira de Medicina Veterinaria 21: 17-20.

—, AND C. DAEMON. 1999. Novo método para marcação de morcegos. Chiroptera Neotropical 5: 116-117.

- A. G. Motta, D. M. Oliveira, A. F. Áreas, R. T. V. RoDRIGUES, AND H. G. BERGALlo. 2003. Observações de fidelidade ao refúgio em Molossus rufus no Estado do Rio de Janeiro, sudeste do Brasil. Chiroptera Neotropical 9(1-2): 175-178.

Fenton, M. B., I. L. Rautenbach, J. Rydell, H. T. Arita, J. Ortega, S. Bouchard, M. D. Hovorka, B. Lim, E. Odgren, C. V. Portfors, W. M. SCully, D. M. SYME, AND M. J. Vonhof. 1998. Emergence, echolocation, diet and foraging behavior of Molossus ater (Chiroptera: Molossidae). Biotropica 30: 314-320.

LEWIS, S. E. 1995. Roost fidelity of bats: A review. Journal of Mammalogy 76: 481-496.

Margolis, L., G. W. Esch, J. C. Holmes, A. M. Kuris, and G. A. SCHAD. 1982. The use of ecological terms in parasitology (report of an ad hoc committee of the American Society of Parasitologists). Journal of Parasitology 68: 131-133.

MARques, S. A. 1986. Activity cycle, feeding and reproduction of $\mathrm{Mo}$ lossus ater (Chiroptera: Molossidae) in Brazil. Boletim do Museu Paraense Emilio Goeldi 2: 159-179.

Marshall, A. G. 1991. The ecology of ectoparasitic insects. Academic Press, New York, 445 p.

Wilson, K., O. N. Buørnstad, A. P. Dobson, S. Merler, G. Poglayen, S. E. Randolph, A. F. Read, ANd A. Skorping. 2002. Heterogeneities in macroparasite infections: Patterns and process. In Ecology of wildlife diseases, P. J. Hudson, A. Rizzoli, B. T. Grenfell, H. M. Heesterbeek, and A. P. Dobson (eds.). Oxford University Press, Oxford, U.K., p. 6-44. 